\title{
Hubungan Hiperbilirubinemia dan Kematian Pasien yang Dirawat di MICU RSUP Dr Kariadi Semarang
}

\author{
M. Sholeh Kosim, Lisa Adhia Garina, Tony Chandra, M. Sakundarno Adi \\ Bagian Ilmu Kesehatan Anak FK Universitas Diponegoro/RS. Dr. Kariadi Semarang
}

\begin{abstract}
Latar belakang. Hiperbilirubinemia merupakan salah satu masalah kegawatan pada bayi baru lahir. Peningkatan unconjugated bilirubin serum sampai dengan kadar $20 \mathrm{mg} / \mathrm{dl}$ sering menyebabkan "kern ikterus", sehingga fungsi otak terganggu dan mengakibatkan kecacatan sepanjang hidup atau kematian. Sebagian besar pasien hiperbilirubinemia yang dirawat di NICU mempunyai prognosis yang kurang menggembirakan. Tujuan. Mengetahui hubungan hiperbilirubinemia dan kejadian kematian pasien yang dirawat di NICU RSUP Dr. Kariadi Semarang periode Januari 2005 - November 2006

Metode. Studi observasional retrospektif pada pasien di bangsal NICU RSUP Dr. Kariadi Semarang, Januari 2005 - November 2006. Variabel yang diteliti ialah karakteristik umum (masa gestasi, berat badan lahir, cara persalinan, kejadian sepsis) yang merupakan faktor risiko hiperbilirubinemia dan hubungan hiperbilirubinemia terhadap hasil keluaran (hidup atau mati). Kadar bilirubin diperiksa pertama kali pada saat ditemukan ikterus. Analisis statistik menggunakan program SPSS versi 11.5 for Windows.

Hasil. Dari 90 pasien dengan ikterus neonatorum, $71(78,9 \%)$ pasien mempunyai kadar bilirubin $=10 \mathrm{mg} / \mathrm{dL}$. Limapuluh tiga $(58,9 \%)$ pasien BBLR, $50(55,6 \%)$ preterm dan 54 (60\%) lahir spontan. Limapuluh tujuh bayi (69,5\%) pasien dengan sepsis awitan dini, 33 bayi ( $30.5 \%$ ) awitan lambat. Angka kematian $80 \%$ dan sebagian besar $65(90,3 \%)$ disebabkan oleh sepsis. Tidak didapatkan hubungan antara hiperbilirubinemia dan hasil keluaran. Sepsis awitan lambat merupakan faktor risiko terjadinya hiperbilirubinemia OR 32,3 (95\% CI 7,8 - 125) dan partus dengan tindakan juga merupakan faktor risiko terjadinya hiperbilirubinemia OR 4,5 (95\% CI 1,5 - 13,3). Kesimpulan. Sepsis awitan lambat dan partus dengan tindakan merupakan faktor risiko terjadinya hiperbilirubinemia pada pasien yang dirawat di NICU. (Sari Pediatri 2007; 9(4):270-3).
\end{abstract}

Kata kunci: hiperbilirubinemia, faktor risiko

Alamat korespondensi

Sholeh Kosim, dr., Sp.A (K)

Sub Bagian Perinatologi Bagian IKA FK UNDIP/RS.Dr. Kariadi Semarang email: mskosim@indosat.net.id
$\mathrm{I}$

kterus neonatarum atau hiperbilirubinemia pada neonatus sering ditemukan pada minggu pertama setelah lahir terutama pada bayi kecil (<2500 gram) dan kurang bulan $(<37 \text { minggu })^{1}$. Insiden hiperbilirubinemia di Amerika 65\%, Malaysia 
$75 \%$, sedangkan di Surabaya 30\% pada tahun 2000, dan $13 \%$ pada tahun $2002 .{ }^{2}$ Ikterus atau jaundice terjadi akibat akumulasi bilirubin dalam darah sehingga kulit, mukosa dan atau sklera bayi tampak kekuningan. Hiperbilirubinemia merupakan istilah yang dipakai untuk ikterus neonatorum setelah ada hasil laboratorium yang menunjukkan peningkatan kadar bilirubin. Ikterus akan tampak secara visual jika kadar bilirubin lebih dari $5 \mathrm{mg} / \mathrm{dl}^{3}$

Hiperbilirubinemia adalah keadaan yang umum terjadi baik pada bayi preterm maupun aterm. Peningkatan kadar bilirubin $>2 \mathrm{mg} / \mathrm{dL}$ sering ditemukan pada hari-hari pertama setelah lahir $60 \%$ dari bayi baru lahir mengalami ikterik (kadar bilirubin $>5 \mathrm{mg} / \mathrm{dL}) .{ }^{4}$ Pada umumnya, peningkatan kadar bilirubin tidak berbahaya dan tidak memerlukan pengobatan. Namun pada beberapa kasus dapat berhubungan dengan beberapa penyakit, seperti penyakit hemolitik, kelainan metabolik dan endokrin, kelainan hati, dan infeksi., ${ }^{5,6}$ Pada kadar lebih 20 mg/ $\mathrm{dl}$, bilirubin dapat menembus sawar darah otak (blood brain barrier) sehingga bersifat toksik terhadap sel otak. ${ }^{5}$ Peningkatan bilirubin serum akan menyebabkan bilirubin yang belum dikonjugasi di hati atau unconjugated bilirubin masuk ke dalam sel saraf dan merusaknya, disebut kern-ikterus. Pada kern-ikterus fungsi otak terganggu dan mengakibatkan kecacatan sepanjang hidup atau kematian., ${ }^{2,4}$

Penelitian bertujuan mengetahui hubungan kadar bilirubin dengan kematian serta faktor-faktor karakteristik umum yang berhubungan dengan hiperbilirubinemia.

\section{Metode}

Penelitian dengan desain observasional retrospektif berdasarkan data sekunder dari catatan medik pasien yang dirawat di bangsal NICU RS Dr Kariadi Semarang, pada periode bulan Januari 2005 November 2006. Semua catatan klinis yang lengkap, diikutsertakan dalam penelitian.Variabel yang diteliti adalah karakteristik umum, kadar bilirubin, kejadian sepsis awitan dini dan lambat, hasil keluaran berupa hidup dan mati. Diagnosis hiperbilirubinemia didasarkan klinis dan kadar bilirubin serum diperiksa pertama kali pada saat ditemukan ikterus. Risiko kematian dari hiperbilirubinemia dianalisis dan hasil ditampilkan dalam rasio risiko dengan tingkat kepercayaan 95\%. Analisis statistik menggunakan program SPSS versi 11.5 for Windows.

\section{Hasil}

Ditemukan 90 subjek pasien hiperbilirubinemia yang dirawat di NICU yang memenuhi kriteria inklusi. Karakteristik umum subjek tertera pada Tabel 1.

Dari Tabel 2, tampak tidak ada hubungan bermakna secara statistik antara kadar hiperbilirubinemia dengan masa gestasi, berat lahir, jenis partus, dan keluaran. Sedangkan pada awitan sepsis terdapat hubungan yang

Tabel 1. Karakteristik umum penderita Hiperbilirubinemia di NICU RSDK

\begin{tabular}{|c|c|c|}
\hline Karakteristik & $\mathrm{n}$ & $\%$ \\
\hline \multicolumn{3}{|l|}{ Umur (jam) } \\
\hline$<72$ & 18 & 20,0 \\
\hline$\geq 72$ & 72 & 80,0 \\
\hline \multicolumn{3}{|l|}{ Jenis kelamin } \\
\hline Laki-laki & 48 & 53,3 \\
\hline Perempuan & 42 & 46,7 \\
\hline \multicolumn{3}{|l|}{ Berat badan lahir (gram) } \\
\hline$<2500$ & 53 & 58,9 \\
\hline $2500-3999$ & 37 & 41,1 \\
\hline$>4000$ & 0 & 0,0 \\
\hline \multicolumn{3}{|l|}{ Masa gestasi (minggu) } \\
\hline$<37$ & 50 & 55,6 \\
\hline $37-40$ & 40 & 44,4 \\
\hline$>41$ & 0 & 0,0 \\
\hline \multicolumn{3}{|l|}{ Jenis partus } \\
\hline Spontan & 54 & 60,0 \\
\hline Tindakan & 36 & 40,0 \\
\hline \multicolumn{3}{|c|}{ Kadar bilirubin total (mg/dl) } \\
\hline$<10$ & 19 & 21,1 \\
\hline$>10$ & 71 & 78,9 \\
\hline \multicolumn{3}{|l|}{ Jenis sepsis } \\
\hline Awitan dini & 57 & 69,5 \\
\hline Awitan lambat & 25 & 30,5 \\
\hline \multicolumn{3}{|l|}{ Keluaran } \\
\hline Hidup & 18 & 20,0 \\
\hline Mati & 72 & 80,0 \\
\hline \multicolumn{3}{|l|}{ Penyebab kematian } \\
\hline Sepsis & 65 & 90,3 \\
\hline Asfiksia & 5 & 6,9 \\
\hline Preterm & 1 & 1,4 \\
\hline Hiperbilirubinemia & 1 & 1,4 \\
\hline
\end{tabular}


Tabel 2. Hubungan hiperbilirubinemia dengan faktor risiko

\begin{tabular}{|c|c|c|c|c|c|}
\hline \multirow{2}{*}{ Faktor risiko } & & \multicolumn{2}{|c|}{ Kadar bilirubin total } & \multirow{2}{*}{ Total (\%) } & \multirow{2}{*}{$\mathrm{P}$} \\
\hline & & $<10 \mathrm{mg} / \mathrm{dl}(\%)$ & $\geq 10 \mathrm{mg} / \mathrm{dl}(\%)$ & & \\
\hline \multirow{3}{*}{$\begin{array}{l}\text { Umur kehamilan } \\
\text { (minggu) }\end{array}$} & $<37$ & $10(20,0)$ & $40(80,0)$ & $50(55,6)$ & \\
\hline & $37-41$ & $9(22,5)$ & $31(77,5)$ & $40(44,4)$ & \\
\hline & Total & $19(21,1)$ & $71(78,9)$ & $90(100,0)$ & $\mathrm{p}=0,97$ \\
\hline \multirow{3}{*}{$\begin{array}{l}\text { Berat lahir } \\
\text { ( gram) }\end{array}$} & $<2500$ & $11(20,8)$ & $42(79,2)$ & $53(58,9)$ & \\
\hline & $2500-4000$ & $8(21,6)$ & $29(78,4)$ & $37(41,1)$ & \\
\hline & Total & $19(21,1)$ & $71(78,9)$ & $90(100,0)$ & $\mathrm{p}=1,00$ \\
\hline \multirow[t]{3}{*}{ Jenis Partus } & Spontan & $6(11,1)$ & $48(88,9)$ & $54(60,0)$ & $\mathrm{p}=0,01$ \\
\hline & Tindakan & $13(36,1)$ & $23(63,9)$ & $36(40,0)$ & OR: 4,5 \\
\hline & Total & $19(21,1)$ & $71(78,9)$ & $90(100,0)$ & $(95 \%$ CI: $1.5-13,3)$ \\
\hline \multirow[t]{3}{*}{ Sepsis } & Awitan dini & $3(5,3)$ & $54(94,7)$ & $57(69,5)$ & $\mathrm{p}<0,001$ \\
\hline & Awitan lambat & at $16(64,0)$ & $9(36,0)$ & $25(30,5)$ & OR 32,3 \\
\hline & Total & $19(23,2)$ & $63(76,8)$ & $82(100,0)$ & (95\% CI: 7,8-125) \\
\hline \multirow[t]{3}{*}{ Keluaran } & Hidup & $3(16,7)$ & $15(83,3)$ & $18(20,0)$ & \\
\hline & Mati & $16(22,2)$ & $56(77,8)$ & $72(80,0)$ & \\
\hline & Total & $19(21,1)$ & $71(78,9)$ & $90(100,0)$ & $\mathrm{p}=0,85$ \\
\hline
\end{tabular}

bermakna secara statistik, sepsis awitan lambat mempunyai risiko 32,3 kali lebih besar terjadi hiperbilirubinemia dibanding sepsis awitan dini.

\section{Diskusi}

Sesuai dengan laporan yang dikemukakan oleh Maisels, dkk. ${ }^{7}$ bahwa proporsi kasus dengan jenis kelamin lakilaki lebih banyak $(53,3 \%)$ daripada perempuan. Penelitian oleh Newman, $\mathrm{dkk}^{8}$ mengemukakan bahwa jenis kelamin merupakan salah satu prediktor hiperbilirubinemia berat pada neonatus.

Dari 90 pasien yang diteliti ditemukan kejadian hiperbilirubinemia terbanyak pada bayi preterm $(55,6 \%)$ walaupun dari penelitian ini tidak ada hubungan bermakna antara masa gestasi dangan kadar hiperbilirubinemia. Penelitian Maisels, $\mathrm{dkk}^{7}$ mendapatkan bahwa hiperbilirubinemia terjadi terbanyak pada bayi preterm (rata-rata umur kehamilan 38,1 \pm 3 minggu). Penelitian yang dilakukan oleh Sarici, $\mathrm{dkk}^{9}$ menemukan bahwa neonatus dengan umur kehamilan 36-37 minggu memiliki faktor risiko 5,7 kali terjadinya hiperbilirubinemia dibandingkan neonatus dengan umur kehamilan 39-49 minggu. Risiko hiperbilirubinemia akan meningkat sesuai dengan menurunnya umur kehamilan (0,6 kali per minggu dari umur kehamilan). Pada penelitian prospektif, neonatus dengan umur kehamilan 35-37 minggu, 2,4 kali mengalami hiperbilirubinemia dibandingkan neonatus dengan umur kehamilan 38-42 minggu, dan menjadi kelompok risiko tinggi. Dari data tersebut disimpulkan bahwa 1 dari setiap 4 bayi preterm memerlukan fototerapi, dibandingkan dengan umur kehamilan dan defisiensi fisiologis enzim uridine diphosphate glucuronyl trasferase. ${ }^{9}$ Ikterus pada bayi prematur timbul pada hari ke 2-5 dan ikterus berat lebih jelas terlihat pada bayi kecil (berat lahir < 2500 gram atau umur kehamilan < 37 minggu). ${ }^{1}$

Dari penelitian yang kami lakukan, didapatkan hubungan bermakna antara awitan sepsis dengan kadar bilirubin, bayi dengan sepsis awitan lambat mempunyai risiko 32,3 kali lebih besar terjadi hiperbilirubinemia dibanding mereka dengan sepsis awitan dini. Pada sepsis awitan lambat timbul implikasi buruk pada berbagai organ, khususnya sistem hepatobilier sehingga kadar bilirubin menjadi lebih tinggi. Hiperbilirubinemia karena sepsis timbul pada hari ke 2-7 setelah lahir dan pada pemeriksaan fisik tampak ikterus berat. ${ }^{1}$ Penelitian yang dilakukan oleh Maisels, $\mathrm{dkk}^{7}$ mendapatkan bahwa sebagian besar neonatus yang dirawat kembali dengan hiperbilirubinemia adalah sehat dan tidak menderita sepsis. Penelitian oleh Sgro $\mathrm{M} \mathrm{dkk}{ }^{10}$ menemukan satu dari 93 kasus $(0,01 \%)$ yang di rawat kembali mengalami sepsis dan menyebabkan hiperbilirubinemia berat. 
Jenis persalinan juga berhubungan dengan hiperbilirubinemia, karena pada persalinan tindakan risiko terjadi infeksi lebih besar dibanding persalinan spontan. Dari penelitian ini didapatkan $40 \%$ persalinan dengan tindakan, sedangkan penelitian oleh Modanlou $\mathrm{dkk}^{11}$ mendapatkan 3 dari 15 kasus $(0,2 \%)$ persalinan dengan vakum ekstraksi mengalami hiperbilirubinemia.

Tampak tidak ada hubungan bermakna antara kadar hiperbilirubin dengan masa gestasi, berat lahir, cara persalinan dan keluaran. Hal tersebut sangat mungkin terjadi karena jumlah subjek penelitian terlalu sedikit, yang juga menjadi salah satu kelemahan pada penelitian ini.

\section{Kesimpulan}

Jenis persalinan dengan tindakan merupakan faktor risiko terjadinya hiperbilirubinemia dan sepsis awitan lambat mempunyai risiko lebih besar untuk terjadi peningkatan kadar bilirubin dibandingkan sepsis awitan dini.

\section{Daftar Pustaka}

1. Kosim MS. Ikterus. Dalam: Buku panduan manajemen masalah bayi baru lahir untuk dokter, bidan dan perawat di rumah sakit. UKK Perinatologi, MNH-JHPIEGO, Departemen Kesehatan RI, 2003. h. 42-9.

2. Indarso F. Transfusi tukar pada neonatus dengan hiperbilirubinemia. Dalam: Makalah lengkap kongres nasional Vll perinasia \& simposium internasional, 2003. h.84-98.
3. Etika R, Harianto A, Indarso F, Damanik SM. Hiperbilirubinemia pada neonatus. Dalam: Permono B, Kaspan F, Soegianto S, Soejoso DA, Narendra MB, Noer MS, penyunting. Continuing education ilmu kesehatan anak, 2004.

4. Gomella TL, Cunningham MD, Eyal FG, Zenk KE, editor. Hyperbilirubinemia, indirect (unconjugated hyperbilirubinemia). Dalam: Neonatology: management, prosedures, on call problems, disease, and drugs. Edisi ke-5. USA: Mosby; 2004. h. 247-50.

5. Porter ML, Dennis BL. Hyperbilirubinemia in the term newborn. Am Fam Phy 2002; 65:599-606.

6. HTA Indonesia. Tatalaksana ikterus neonatorum. Unit Pengkajian Teknologi Kesehatan, Direktorat Jenderal Pelayanan Medik Departemen Kesehatan RI, 2004

7. Maisels MJ, Kring E. Risk of sepsis in newborns with severe hyperbilirubinemia. Pediatrics 1992; 90:741-3.

8. Keren R, Bhutani VK. Predischarge risk assessment for severe neonatal hyperbilirubinemia. Neo Rev 2007; 8: 68-76.

9. Sarici SU, Serdar MA, Korkmaz A, Erdem G, Oran O, Tekinalp G, dkk. Incidence, course, and prediction of hyperbilirubinemia in near term and term newborn. Pediatrics 2004; 113:775-80.

10. Sgro M, Campbell D, Shah B. Incidence and causes of severe neonatal hyperbilirubinemia in Canada. CMAJ 2006; 175:587-90.

11. Modanlou HD. Neonatal Subgaleal Hemorrhage Following Vaccum Extraction Internet Journal of Pediatrics and neonatology. 2005. Volume 5 Number 2. Available in: http://www.ispub.com/ostialindex.php? $x m l F i l e P a t h=j o u r n a l s / i j p n / v o l 5 n 2 /$ vacuum.cml 